\title{
Bland-White-Garland syndrome on coronary CT angiography
}

\author{
Ana Coutinho Santos, ${ }^{1}$ Duarte Martins, ${ }^{2}$ Rui Anjos, ${ }^{2}$ Carla Saraiva ${ }^{1}$
}

'Department of Radiology, Centro Hospitalar de Lisboa Ocidental EPE, Lisboa, Portugal ${ }^{2}$ Department of Paediatric Cardiology, Centro Hospitalar de Lisboa Ocidental EPE, Lisboa, Portugal

\section{Correspondence to} Dr Ana Coutinho Santos, a.icoutinho.santos@gmail.com

Accepted 25 March 2018

\section{DESCRIPTION}

A 2-month-old infant presented with poor weight gain, feeding intolerance and cardiomegaly on chest radiography. Transthoracic echocardiography showed severe left ventricular dilatation and dysfunction, left atrial dilatation, moderate mitral regurgitation and doubtful origin of left coronary artery (LCA). Cardiac catheterisation did not identify the origin of LCA from the aorta. Coronary CT angiography (128-multidetector CT, retrospective ECG-gated with restrictive dose modulation, $70 \mathrm{kVs}, 1.2 \mathrm{mSv}$ ) revealed the origin of the LCA from the pulmonary artery trunk/root junction, immediately above the sinus of Valsalva and was consistent with remaining echocardiography findings (figure 1). The right coronary artery had normal origin. After surgical reimplantation of the LCA in the ascending aorta there was good clinical evolution, with significant weight gain and gradual left ventricular function improvement.

Anomalous LCA from the pulmonary artery, also known as ALCAPA or Bland-White-Garland (BWG) syndrome, is very rare, corresponding to

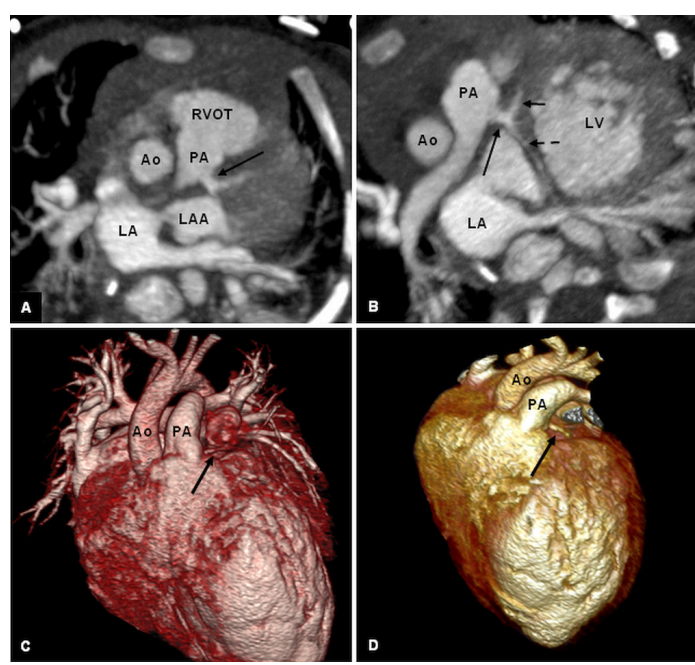

Figure 1 Anomalous left coronary artery from the pulmonary artery (PA) trunk/root junction on multidetector coronary $C T$ angiography. (A) Origin of the left coronary artery (arrow) on the left aspect of PA. (B) The left coronary artery (long arrow) divides into two main arterial branches with course corresponding to the left anterior descending artery (short arrow) and the left circumflex artery (short dashed arrow). (C, D) Volumetric three-dimensional (3D) reconstructions depicting abnormal origin of the left coronary artery (arrow). Ao, aorta; LA, left atrium; LAA, left atrial appendage; LV, left ventricle; RVOT, right ventricular outflow tract.

\section{Learning points}

- Anomalous left coronary artery from the pulmonary artery is very rare and associated with high mortality rate in the first year of life.

- Timely diagnosis and surgical correction of this condition are crucial for the recovery of myocardial function. Multimodality cardiovascular imaging has a very important role in this setting.

- Coronary CT angiography allows a non-invasive accurate diagnosis, depicting the origin and course of the coronary arteries. Additionally, it offers a three-dimensional assessment of the anatomic relations between coronary arteries and adjacent structures, useful for surgical planning.

$0.25 \%-0.5 \%$ of all congenital cardiac anomalies. ${ }^{12}$ BWG syndrome is usually diagnosed in the first 2 months of life and can be isolated or associated with other congenital anomalies. ${ }^{3}$ There are two types of BWG syndrome: the infant type and the adult type. Without corrective surgery, mortality rate is approximately $90 \%$ in the first year of life, resulting from myocardial ischaemia with secondary left ventricular dysfunction, myocardial infarction, mitral insufficiency or fatal arrhythmias. ${ }^{1-3}$ Prognosis and survival to the adult age depend on the development of extensive collateral circulation from the right coronary artery, which characterises the adult type. ${ }^{23}$ Early diagnosis allows timely surgical correction and prevention of potential complications. ${ }^{1}$ ECG-gated multislice CT angiography is an important diagnostic tool combined with other imaging techniques as it provides a fast and accurate depiction of the origin and course of the coronary arteries. The high spatial resolution and capability of multiplanar reconstructions are essential to the surgical planning. ${ }^{2}$

Contributors ACS was involved in manuscript preparation and review of the bibliography, and image editing. CS was involved in case selection and image editing. DM, RA and CS critically reviewed the manuscript.

Funding The authors have not declared a specific grant for this research from any funding agency in the public, commercial or not-for-profit sectors.

Competing interests None declared.

Patient consent Obtained.

Provenance and peer review Not commissioned; externally peer reviewed. 


\section{Images in...}

(c) BMJ Publishing Group Ltd (unless otherwise stated in the text of the article) 2018. All rights reserved. No commercial use is permitted unless otherwise expressly granted.

\section{REFERENCES}

1 Ling Y, Bhushan S, Fan Q, et al. Midterm outcome after surgical correction of anomalous left coronary artery from the pulmonary artery. J Cardiothorac Surg 2016;11:137.
2 Heermann P, Heindel W, Schülke C. Coronary artery anomalies: diagnosis and classification based on cardiac CT and MRI (CMR) - from ALCAPA to anomalies of termination. Rofo 2017;189:29-38.

3 Duan $\mathrm{X}$, Yu T, Wang F, et al. Anomalous origin of the left coronary artery from the pulmonary artery in infants: imaging findings and clinical implications of cardiac computed tomography. I Comput Assist Tomogr 2015;39:189-95.

Copyright 2018 BMJ Publishing Group. All rights reserved. For permission to reuse any of this content visit http://group.bmj.com/group/rights-licensing/permissions.

BMJ Case Report Fellows may re-use this article for personal use and teaching without any further permission.

Become a Fellow of BMJ Case Reports today and you can:

- Submit as many cases as you like

- Enjoy fast sympathetic peer review and rapid publication of accepted articles

- Access all the published articles

Re-use any of the published material for personal use and teaching without further permission

For information on Institutional Fellowships contact consortiasales@bmjgroup.com

Visit casereports.bmj.com for more articles like this and to become a Fellow 